「若手による地場産業」レポート

\title{
文化学園テキスタイル資料館
}

今回, 私がレポートをしたのは西新宿にある文化学園 テキスタイル資料館である。私の通う学校の施設だが詳 しく知りたいので, 実際に資料館を訪れて話を伺うこと にした。幸い，館員の佐川貴則課長にいろいろ話を伺う ことができまま私自身もパンフレットを読むなどして 資料館についてわかりやすくまとめてみた。

\section{1. 開館とその目的}

文化学園テキスタイル資料館は1994年（平成 6 年）の 7 月 1 日に文化学園の教育・研究施設の一つとして独立 し開館された。服装教育・研究を中心に行なう文化学園 にはその関連施設として図書館や服飾博物館などが既に 開館されているが, 服飾素材に関しての資料展示, 情報 の場は十分とはいえなかったため,この様な内容を中心 に収集し，情報は提供する施設として資料館が設けられ た。現在, 館長は文化女子大学の石川欣造先生が務めて おり，館員は館長を含めて 6 人で構成されている。

\section{2. 資料館の特徵・内容}

この資料館には常時 6000 点を超えるテキスタイル資料 が展示されている。これらの資料は基本的な素材から最 新の素材まで幅広い収集がされているが, 直接手で触れ ることができるようにハンガー見本として展示されてい る。資料の展示はその素材の材質別として綿, 絹, 毛, 麻, 化合緎, 皮革などの分類や, 構成や特徵別として織 物, 編物, キルティング, 最新素材, 透ける素材, 光る 素材, 装飾された素材などに細かく区分がされており, 大変資料が見やすく感じられる。

この資料の一つ一つに整理番号が付いており, コンピ ユータによる検索ができるように管理されている。テキ スタイルに関連する書籍やカラーボックスと呼ばれる色 別に分けられた織物の資料なども揃えられ、テキスタイ ルに関して総合的に情報が得られる構成となっている。 以下にそれぞれの内容について簡単に記していく。

コンピュータによる検索は文化学園の開発した「文化

\section{文化女子大学大学院 堀 江 恵 子}

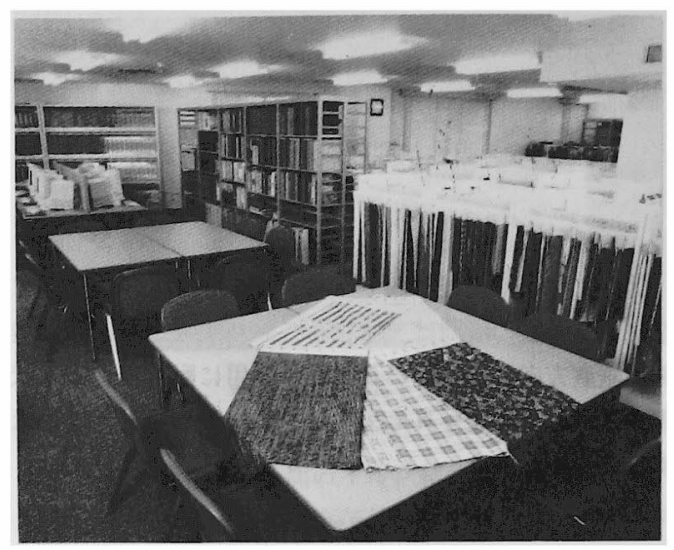

写真 1 資料館の一室

学園テキスタイル検索システム」により行われる。まず テキスタイルについて得られる生地名, 材質, 組織, 柄, 加工, 特性, 用途などの情報が項目として分けられ， ワ ークステーションに入力, 蓄積されている。そして検索 用として10台の端末機が用意されており，コンピュータ に不慣れな人でも，マウス操作だけで自由に情報が得ら れるようにシステム化されている。また実物資料が同時 に得られるようにA 4 サイズの資料ファイルがテキス夕 イルフォルダー自動収納庫に収められ、コンピュータと 連動して管理されている。

このシステムの検索方法は 2 通りに分けられる。まず 直接検索であるが，この方法は任意に選んだハンガー見 本上に記載されている整理番号を，検索画面に入力する ことでその資料の情報を直接得るものである。次に条件 検索であるが，これは目的に沿う資料をコンピュータで 検索する方法であり，画面に表示されている各項目から 目的，条件などをいくつか選び，入力する手順をとる。 例えば，春夏の綿を使ったコートに適した生地名を得た い場合，項目でコートを選んで検索すると「ッイル」な どの生地名が表示される。そして画面上でファイル出力 というボタンを押すと自動収納庫から該当するファイル 
が飛び出してくる。ここでファイルから実物資料を取り 出して直接に触れることもできるが，画面上の所在番号 加ららに大きなハンガー見本のストック場所まで判る ようになっている。

これら検索用に使用するコンピュータは，既にインス トールされている他のテキスタイル関連ソフトを使うこ とで検索以外の利用もできる。現在は，組織や系の太さ や色などを自由に設定し先染織物のデザインが出来るも の，自分の描いたデザイン画に資料館の展示資料を貼り 込んだり，好きな色をつけたりすることのできるものな どがあり，実際に利用もされている。これらのソフトの 利用で完成した画面はカラー出力ができ, 資料として, 持ち帰ることができる。但し，出力に関する費用は有料 になっている。

カラーボックスは最近になって設けられた盗料の一つ である。色を縦にトーンを11段階，横に色相を10段階に 分けた引出しで, 引出しの表面には色の表示がされてい る。各引出しの中にはその表示色に近い無地の織物が, 天然䄉維と化学轾維とに分けて入っている。この設置の 目的は織物の材質，構成などで微妙に異なる色との関係 を実物資料で見て，感覚を磨いてもらいたいということ からきている。この実物資料の大きさは手帳サイズ程で 自由に持ち帰る事ができ，テキスタイルに関連する本学 の学生が様々に利用している。

テキスタイルに関連した書籍は主に実物サンプルを貼 クつけたバインダー式の本である。今までのこうした本 は写真や絵によるサンプルで，柄について扱ったものが 多かった。またここにある実物の貼られた本は多くの 柄別に分かれているものの他，1994年春夏物などとシー ズン別に分かれた衣料素材のものも集められ，様々なイ メージが得られやすくなっている。この他の書籍には，

较維，加工，流行色などを扱った情報誌や事典などが置 かれているが, 本学の図書館に多数揃っているために, 少数の収集となっている。また，同しく関連したビデオ テープも収集しているが，数としてはまだ少ない。

こうした様々な資料は全て入館者が自由に利用，閲覧 することができる。わからないことがある時は館員に尋 ねれば丁寧に教えてもらえるので遠虑なく聞くとよい。

\section{3. 資料の収集方法}

資料館の資料の収集は原則として無傥の提供によって 集められている。その提供者を大まかに分類すると次の 通りである。

1、䄉維産業の協会, 振興会などの組織

2. 各企業のメーカー単位

3, 各地の問屋, 産地など個別単位
4. 毎年開かれる各種素材展の展示サンプル

現時点では無償の提供という性格から，天然故維より

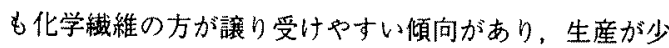
なく高価な䅌は収集に苦労した布地の一つであった。こ うして集められたテキスタイルは新しく資料となる時に 情報を取り，険索システムに入力する。カラーボックス に使われる資料は展示資料の余ったものが用いられる。

書籍類はほとんどが購入によって集められている。こ の中の一部の書籍は会貝制をとるものがあり，その場合 は会貝となっている。ビデオは提供をされるものが多い。

\section{4. 資料館の活功}

資料館の開館には一般開館日が設けられ，火曜，水曜 日の 9 時30分から16時30分までとなっている。この時間 は何時でも入館ができる。また, 事前の電話連絡で予約 を取れば他の曜日も入館が可能である。開館日には学生 を中心に約50〜100人ほどが様々な目的で来館している。 入館に際しては, 文化学園関係者は学生証などの提示が 必要であるが, 学外関係者の場合は事前の電話連絡をし て頂きたいそうである。

行事としては，定期的にテキスタイル講座、テキスタ イル素材展とセミナーが開かれている。

まずテキスタイル講座は年に $1 ， 2$ 回の開催を目標に テーマを持って，それぞれ専門分野の方を講師に迎えて 催されている。昨年の（1994年）12月に第 1 回「皮革」 が開かれて以降，第 2 回「抗菌素材, 第 3 回「皮革 $2 」$ と順調に開催されている。私は第 3 回目の講座に初めて 参加したが，皮革の仕入れから加工，製品化までを手掛 ける会社の社長が講師であり，皮革の種類，産地につい てから加工工程までの話を講義された。話だけではなく， 様々な皮革を現物で提示したり，ビデオによる現場の様 子が織りまぜられており，誰にでも理解できるように工 夫がされていた。特に皮革についての講義は、これから もシリーズとして開催して行くそうである。

次にテキスタイル素材展とセミナーについてであるが， これらは同時開催で年に1度，秋ごろに開かれている。 資料館の開館以前より開かれていた行事であり，ここ数 回はレーヨンフィラメントについての紹介をする内容と なっている。以前開催された時に参加したことがあるが， その時の素材展は素材が展示, 紹介されているだけでは なく，その素材を用いて，本学を卒業したデザイナーが デザインして製作した服も並んで㧍り，明るくさわやか な䨌囲気のある展示会であった。また，七ミナーはレー ヨンについての基本的な事柄加らこれからの可能性な どをメーカーの方が講義する内容であった。

これらの講座，七ミナーは定員が設けられている程、 


\section{受講生が多い。}

資料館では今年（1995年）4月より「資料館だより」 が発行されるようになった。4 ページほどのミニ冊子で あり, 年 2 回の発行を予定している。第 1 号の内容は, 館長や本学の先生方によるテキスタイルに対する寄稿, 専門用語の説明, 資料館に所蔵, 展示されている新素材 の解説，開催された行事についての記事で構成されてい た。この中でも特に興味深かったのは，マテリアルフラ ッシュと題された新素材の解説の記事であった。小さい スペースであるが，写真を用いて簡潔に製法や特色など がまとめられてあり，とても読みやすいものであった。

こうした開館以外の活動は館貝の少なさもあり大変で あると推察できるが,このまま続けて欲しいと思う。

\section{5. 資料館の組織形態}

さらに資料館には運営委員会と専門委員会の組織があ り，各委員会とも文化女子大学，文化服装学院の教員か ら構成され，定期的に委員会を開いている。各委員会で は資料館の運営, 内容, 機能の充実や行事のテーマ, 日 程の決定など資料館の方向づけに関して，また，資料の まとめ方ゃ統一方法などに関して細かい助言をしている。

以上，テキスタイル資料館のレポートとして，私見を 交えて書いてきたが，資料館の館長である石川欣造先生 に資料館の今後の展望を伺うと, 次の通りに語られた。 「この資料館ではテキスタイル情報が実物資料とともに 得ることができますが，更に手で触れることで利用者が 理解しやすいような配慮をしています。今日ではテキス タイルに関しての情報は多様化しており，利用する方に よって必要とする情報が異なっています。それぞれの目 的に沿い，多くの方に有効，適切な利用ができるように， 資料館としてもこれから十分に充実させて行くつもりで す。将来，我が国を代表し，世界にも通用する程の誇れ る施設になることが，私の資料館への思いであります。」

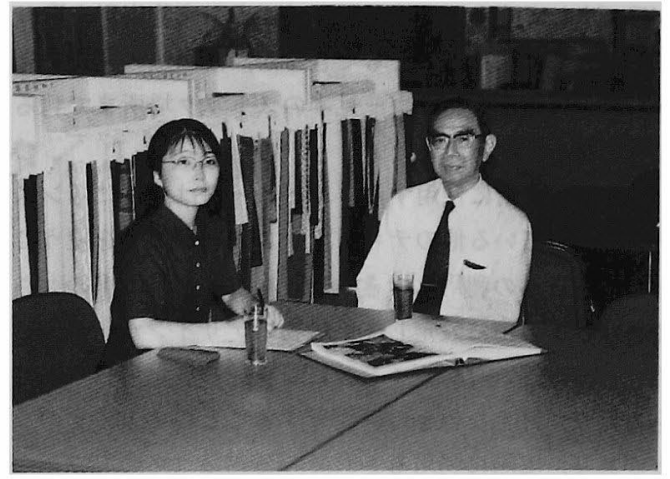

写真 2 石川欣造館長と著者

私は資料館について展示資料と検索システムの立派な 事は知っていたが，今回のレポートで何回も訪れたこと で，非常に価値のある施設であることが分かるようにな った。何故ならば，今までの教科書や事典などで得るこ とのできるテキスタイルの情報は言葉や写真による情報 だけであり，平面的であった。また，個人的にその実物 資料を手に入れることは難しいことである。しかしここ の資料館には多くの実物資料があるうえ，触れることで 感覚的に理解でき，その情報量は立体的になる。テキス タイルの情報も能率的に管理されているため, 簡単に得 ることができ，総合的なテキスタイルの情報スペースと なっている。これからも，種々雑多なテキスタイルが現 れることは間違いなく，その時こそ，資料館の情報スペ 一スとしての役割がさらに増していくことになるだろう。 私も積極的な利用を心掛け，石川館長の言葉の通りにこ の資料館が日本を代表する素晴らしい施設となるように 期待をしたいと思う。

最後に，今回本稿をまとめるに当たり，資料館の副館 長である成瀬信子先生にご指導を頂いたので，感謝の念 を表したい。

(平成 7 年 7 月 31 日受理) 